\title{
Analysis of operating conditions of heavy- loaded and heat-stressed friction units of powerful internal combustion engines and development of copper nanocomposite powder materials for them
}

\author{
Evgeny Shalunov ${ }^{1}$, Sergey Shalunov ${ }^{2}$, and Yulia Vladimirova $^{1, *}$ \\ ${ }^{1}$ Chuvash State University, Joint R\&D Laboratories of mechanically alloyed nanocomposite \\ Materials, their Technology and Quality, 428015 Cheboksary, Moscovsky Prospekt 15, Russia \\ 2 Arloid Automation Pte Ltd., 018982 Singapore, Marina Boulevard 12, Singapore
}

\begin{abstract}
The article provides analysis of operating conditions for the «valve - valve guide» heavy-loaded and heat-stressed friction unit of the gas distribution mechanism of powerful internal combustion engines and establishes requirements to materials for valve guides. It describes nanoc omposite materials based on copper powder with aluminum, carbon, iron and oxygen additives developed by the authors of the present article. The reactionary mechanical alloying method and powder metallurgy technologies in use made it possible to develop materials having a dispersion-strengthened structure with nano-disperse level sizes of structural components (dispersoids, subgrains). They have a recrystallization temperature of over $950^{\circ} \mathrm{C}$, good therm-conductivity, a low linear thermal expansion coefficient and excellent tribotechnical properties. For example, a copper nanocomposite material containing 0.9 wt $\%$ aluminum, 0.3 wt $\%$ carbon, 0.4 wt $\%$ iron and 0.017 wt $\%$ oxygen, by its tribotechnical properties, greatly surpasses CuNi2Si (F65 DIN 17666) bronze widely used by many leading engine-making companies for production of valve guides. By their properties, the developed materials meet requirements that have to be imposed on modern and promising materials for valve guides of powerful internal combustion engines.
\end{abstract}

\section{Introduction}

In internal combustion engines a number of friction units («piston - cylinder liner», «plain bearing - shaft», «valve seat - valve», etc.) experience the impact of high loads and temperatures during engine operation $[1,2]$. However, one of the most heavy-loaded and heat-stressed friction units, especially in powerful and highly-forced engines, is the tribocoupling «valve guide - valve» (Fig. 1) of the engine gas distribution mechanism [3, 4].

\footnotetext{
* Corresponding author: yulivladimirova@mail.ru
} 


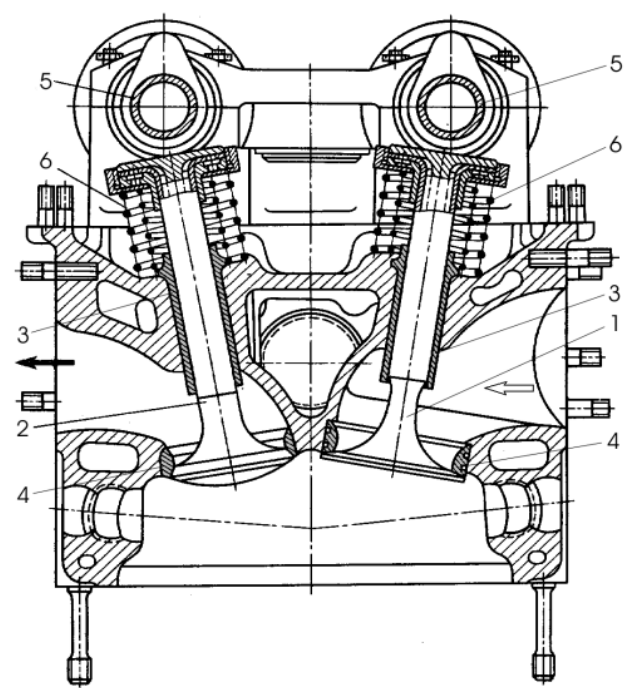

Fig. 1. Drive of two rows of valves by two distribution shafts: 1 - inlet valve; 2 -exhaust valve; 3 - valve guides; 4 - valve seats; 5 - camshafts; 6 - springs.

The valve, being heated during operation up to $1000^{\circ} \mathrm{C}$, is the most heat-stressed engine part [5]. It is in permanent contact with its guide and during operation it moves in a reciprocating motion in it. As a result, the valve guide can heat up to $90 \%$ of the heating temperature of the valve itself [6].It should be added to the above said that the given tribocoupling is also under impact of an aggressive medium, which is explained by gases moving at the speed of $400 \ldots 600 \mathrm{~m} / \mathrm{s}$. The heating temperature of these gases reaches the level of $1202^{\circ} \mathrm{C}$ [6]. As a result of the valve reciprocal motion in the guide both the valve stem and the guide hole wear out. Due to this the gap between these parts increases.

The valve guide wear-out can cause the following valve damages: melting of its head, cracks in valve fillets, cracks in valve keeper grooves, excessive wear-out of the valve stem end, worn-out or burnt valve seat rings. If the gap between the valve stem and the guide is excessive, the valve stem can bend and break at the joint of the stem and head. This inevitably leads to a failure of the whole engine.

To ensure a long life of the gas distribution mechanism one, first of all, should pay attention to materials used for making valves and guides as in most cases the cause of failures of this mechanism is incorrect selection of materials for the given purposes. By present, a great variety of materials (steels, nickel and titanium alloys, ceramic materials and other) have been developed the wear-out rate of which is significantly lower than that of valve guides $[2,5]$. Therefore, when selecting materials, one should, first of all, pay attention to materials for valve guides.

Analysis of operating conditions of modern and promising powerful internal combustion engines, including forced diesel ones, made it possible to establish basic requirements to materials for valve guides. In particular, they should have a thermoconductivity that is not less than $15 \%$ of thermo-conductivity of pure copper. At that, the recrystallization temperature should be not less than $900^{\circ} \mathrm{C}$, while the linear thermal expansion coefficient should be within the range from $17.5 \cdot 10^{-6} 1 /{ }^{\circ} \mathrm{C}$ to $23.0 \cdot 10^{-6} 1 /{ }^{\circ} \mathrm{C}$ at temperatures from $100^{\circ} \mathrm{C}$ to $900^{\circ} \mathrm{C}$. The Vickers hardness number should be min. 2000 MPa. Comparing to standard materials now in use, it should have higher tribotechnical properties. Also, the material should be ecologically clean.

Manufacturers of engine parts make valve guides of gray cast irons, steels, bronzes and brasses. Gray cast iron for valve guides should have a fine-grained perlite microstructure. 
Phosphorus is added to the material composition for forced engines to reduce friction and wear-out and chromium is added for supercharged engines. As a rule, valve guides made of these materials are strong and rather wear-resistant; however, their disadvantage is low thermal conductivity. Besides, in some cases, particularly during alloying of gray cast iron with chromium, one can observe abrasive wear-out of the valve itself. Steel guides based on $\mathrm{Fe}-\mathrm{C}$ system have, as a rule, the wear-out rate of $10 \ldots 20 \mu \mathrm{m}$, while the wear-out rate of cast-iron guides is $50 \mu \mathrm{m}$. There is also experience [7] of using sintered materials based on $\mathrm{Fe}-\mathrm{Cu}-\mathrm{C}$ system for valve guides. When such materials are used, one can often see greater wear-out of the valve stem and in case of high porosity - the valve guide itself. These materials have a high linear thermal expansion coefficient, which leads to minimization of the gap between the valve stem and guide. This can cause valve seizure in the guide. Besides, there can be difficulties during mechanical treatment of such materials, which is related to their porosity. Moreover, sintered guides are complex in production and expensive. Therefore, such guides are used rather rarely.

In engines of many manufacturers and, first of all, German companies (BMW, Mercedes, Audi-VW, Porsche, Motoren- und Turbienen Union Friedrichshafen and others) valve guides made of bronze are usually used because they are better in removing heat from heated valves than cast-iron and steels guides. For not too forced engines, these are common copper alloys containing zinc and aluminum, and for more forced motors copper alloys with addition of silicon, nickel and other metals, for example, CuNi2Si F65 bronze, are used [8]. There are also valve guides made of phosphorous bronze designed for joint operation with valves made of Ti-Al system alloys [9]. The friction factor between the valve and its guide made of this bronze can vary from 0.12 to 0.16 . However, when the valve guide is made of cast iron, the friction coefficient values can reach 0.23.

There is experience of application of CuZn40A12 PTL2101 complex alloyed brass in valve guides used in Russian speed cars based on LADA model [6].

No doubt, the above-mentioned dispersion-hardened copper alloys have good tribotechnical properties; however, all of them have an insufficiently high softening temperature. As a rule, it is lower than the temperatures valve guides operate at. This is primarily explained by the fact that at high temperatures fine reinforcing phases (dispersoids) being a part of the copper matrix dissolve in it and do not prevent material grain coarsening [10]. These copper alloys also have a low heat resistance and their application in powerful engines not always provides the required service life of the "valvevalve guide» tribocoupling.

For this reason, the issue of developing copper materials for valve guides capable of operating in the above described conditions and meeting the given requirements still remains relevant.

In distinction to dispersion-hardened copper alloys, dispersion-strengthened copperbased materials have high strength characteristics at high temperatures. This is primarily explained by the fact that their dispersoids do not dissolve in copper matrix and do not interact with it up to the temperature of its melting [10-14]. At that, the material recrystallization temperature is inversely dependent on the size of dispersoids. Besides, the structure of such materials meets the well-known G. Charpy rule (solid particles are evenly distributed in a ductile base), due to which they also should have good anti-friction properties.

In connection with the above said, an attempt was made in the present work to develop anti-friction and heat-resistant nanocomposite materials based on copper powder for valve guides of powerful engines with the use of the mechanism of dispersion strengthening and minimization of sizes of structural components up to the nanodisperse level. 


\section{Experimental materials and methods}

To develop the required material, we used the method of reactionary mechanical alloying in the attritor of powder electrolytic copper PMS-1 (dispersity - $38 \mu \mathrm{m}$ ) with aluminum (in the form of powder PP-1 with dispersity of $75 \mu \mathrm{m}$ ) and carbon (in the form of pencil graphite powder GK-3 with dispersity of $40 \mu \mathrm{m}$ ). The aluminum content in the powder mixture was $2 \mathrm{wt} \%, 3 \mathrm{wt} \%$ and $4 \mathrm{wt} \%$, while the carbon content was determined so that $0.1 ; 0.2 ; 0.3$; 0.4 and 0.5 weight parts of carbon accrued to 1 weight part of aluminum.

Samples of materials were obtained with the use of process operations and equipment given in Table 1.

Table 1. Basic operations, equipment and conditions for obtaining materials under analysis

\begin{tabular}{|c|c|c|c|}
\hline No. & $\begin{array}{c}\text { Brief description of main } \\
\text { operations }\end{array}$ & Main equipment used & Main modes of operation \\
\hline 1 & $\begin{array}{l}\text { Making an initial powder } \\
\text { mixture by joint mixing of } \\
\text { dosed powder quantities }\end{array}$ & $\begin{array}{l}\text { Powder mixer with } 401 \\
\text { capacity }\end{array}$ & Mixing duration $-30 \mathrm{~min}$ \\
\hline 2 & $\begin{array}{l}\text { Initial powder mixture } \\
\text { treatment in the air } \\
\text { atmosphere of the attritor } \\
\text { working chamber }\end{array}$ & $\begin{array}{l}\begin{array}{l}\text { Attritor with a water- } \\
\text { cooled } \\
\text { chamber } \\
\text { capacity }\end{array} \\
\begin{array}{l}\text { with } \\
\text { carking }\end{array} \\
15 \quad 1\end{array}$ & $\begin{array}{l}\text { Rotor rotation speed }-600 \mathrm{~min}^{-1} \text {. } \\
\text { Degree of working chamber } \\
\text { filling with balls and powder } \\
\text { mixture }-0.7 \text {. } \\
\text { Treatment duration }-60 \mathrm{~min} \text {. }\end{array}$ \\
\hline 3 & $\begin{array}{l}\text { Cold pressing of granules } \\
\text { obtained in the attritor in } \\
\text { a rigid matrix acc. to the } \\
\text { double-sided pattern into } \\
\text { briquettes with } 54 \mathrm{~mm} \\
\text { diameter }\end{array}$ & $\begin{array}{l}\text { Hydraulic press with } \\
\text { maximum pressing } \\
\text { force of } 2500 \mathrm{kN}\end{array}$ & Pressure of pressing - $600 \mathrm{MPa}$ \\
\hline 4 & $\begin{array}{l}\text { Heating of briquettes in a } \\
\text { furnace in shielding } \\
\text { atmosphere and further } \\
\text { hot extrusion into bars } \\
\text { with } 13 \mathrm{~mm} \text { diameter } \\
\text { through a conic draw die }\end{array}$ & $\begin{array}{l}\text { Hydraulic press with } \\
\text { maximum pressing } \\
\text { force of } 2500 \mathrm{kN} \text { or } \\
4000 \mathrm{kN}\end{array}$ & $\begin{array}{l}\text { Briquette heating temperature }- \\
850^{\circ} \mathrm{C} \text {. } \\
\text { Heating duration }-20 \text { min. } \\
\text { Hydraulic press container heating } \\
\text { temperature }-450^{\circ} \mathrm{C} \text {. } \\
\text { Extrusion coefficient }-17 .\end{array}$ \\
\hline 5 & $\begin{array}{l}\text { Straightening bars in the } \\
\text { subpress die }\end{array}$ & $\begin{array}{l}\text { Hydraulic press with } \\
\text { maximum pressing } \\
\text { force of } 500 \mathrm{kN}\end{array}$ & $\begin{array}{ll}\text { Straightening } & \text { pressure } \\
300 \ldots 800 \mathrm{MPa} & \end{array}$ \\
\hline 6 & $\begin{array}{l}\text { Cutting of the bar lead-in } \\
\text { and its discard }\end{array}$ & Bandsaw machine & \\
\hline
\end{tabular}

By varying the content of aluminum and carbon (with the constant content of oxygen $0.017 \mathrm{wt} \%$ and iron $-0.4 \mathrm{wt} \%$ ), we obtained materials with a rather wide range of physical and mechanical, process and operation properties.

During the works physical and mechanical properties of obtained materials were determined using corresponding methods. The microstructure was analyzed by means of a microscope with 1200x magnification. The fine structure of the materials was analyzed using the X-ray diffraction method and transmission electron microscopy (TEM). The parameters of the fine structure components (dispersoids, grains) were determined with the use of methods described in [15].

The tribotechnical properties of the materials were determined by means of a modernized friction machine SMZ - 2 in accordance with accelerated testing methods 
based on the well-known «pad-roller» pattern. The maximum pad load was $300 \mathrm{kgf}$. Loading was performed gradually, at the rate of $35 \mathrm{kgf} / \mathrm{h}$. The limit load was reached in $8.5 \mathrm{~h}$.

The pads were made of the materials under analysis, while the rollers - of chromiumplated hardened steel. The reference material for the tests was widely known standard anti-friction bronze F65 acc. to DIN17666, which contains Ni-1.6..2.5 wt \%, Mn-0.8wt\%, $\mathrm{Si}-0.5 \ldots 0.8 \mathrm{wt} \%, \mathrm{Cu}$ - the rest. The Vickers hardness value of this bronze is $2250 \mathrm{MPa}$ at the ultimate tensile strength of $640 \mathrm{MPa}$.

The tests consisted of the following stages:

- warm-up of oil, tools and sensors;

- steplike run-in;

- wear test at a constant load;

- score resistance tests at a continuously increasing load.

Oil, tools and sensors were warmed up during $30 \ldots 40 \mathrm{~min}$ up to a stable temperature of $80 \pm 1^{\circ} \mathrm{C}$.

Run-in of the samples was conducted during $1.5 \mathrm{~h}$ with a steplike load increase of $5 \mathrm{kgf}$ in every $15 \mathrm{~min}$ and was over when the load value of $25 \mathrm{kgf}$ was reached. The wear test duration at the constant load of $25 \mathrm{kgf}$ was $3 \mathrm{~h}$. At the end of these tests the load was reduced by $10 \mathrm{kgf}$ and in $15 \mathrm{~min}$ - up to $35 \mathrm{kgf}$, then again - by $10 \mathrm{kgf}$, following which the machine was switched off. The friction coefficient was determined based on the friction moment value corresponding to the load of $25 \mathrm{kgf}$.

Upon completion of the wear tests the samples were removed, degreased in acetone and weighed. The sizes of the roller-made groove were measured using a toolmaker microscope with $0.01 \mathrm{~mm}$ precision. The groove width was measured in $1 \mathrm{~mm}$. The groove volume $V$, rubbing path $L$ at the roller rotation rate of $500 \mathrm{~min}^{-1}$ and specific pad wear $J_{1}$ as $V / L$ ratio were determined. The specific wear of the chromium-plated roller $J_{2}$ was determined as the ratio of roller weight loss $M_{2}$ to rubbing path $L$.

To evaluate the wear resistance the wear resistance coefficient for valve guide material $K_{1}$ and «pad-roller» junction $K_{1-2}$ were used that were calculated by the following formula:

$$
K_{1}=\frac{J_{1}^{R}}{J_{1}} \quad \text { and } \quad K_{1-2}=K_{1} \times \frac{J_{2}^{R}}{J_{2}},
$$

where $J_{1}^{R}$ - specific wear of a pad made of the standard (reference) material;

$J_{2}^{R}$ - specific wear of a roller working in coupling with a pad made of the standard (reference) material.

To perform score resistance tests the samples were again put to their places, oil, tools and sensors were warmed up, the continuous loading mechanism was switched on. After seizure of the samples, when the torque increased manyfold, the machine stopped automatically.

The score resistance parameter of the junction was the score resistance coefficient $K_{3}$ determined by the formula:

$$
K_{3}=\frac{p}{p^{R}}
$$

where $p^{R}$ - specific seizure load for the «pad-roller» coupling, when the pad is made of the standard (reference) material;

$p$ - specific seizure load for the «pad-roller» coupling, when the pad is made of the material under analysis. 


\section{Experimental results and their discussion}

The results of the tests of developed materials are given in the form of diagrams of dependency of their hardness (Fig. 2) and relative thermo- conductivity (Fig.3) on aluminum and carbon content in the initial powder mixture.

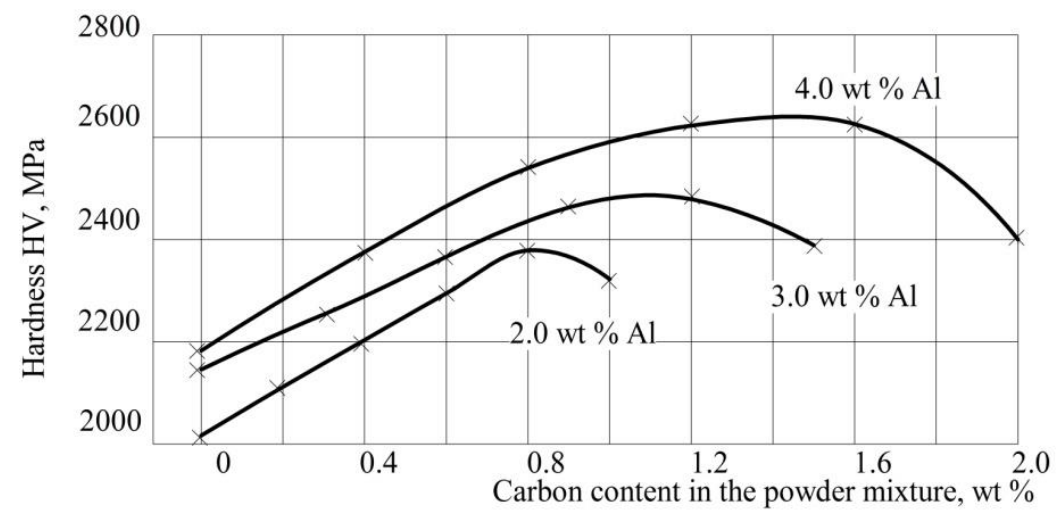

Fig. 2. Diagrams of dependency of Vickers hardness of materials under analysis on their aluminum and carbon content.

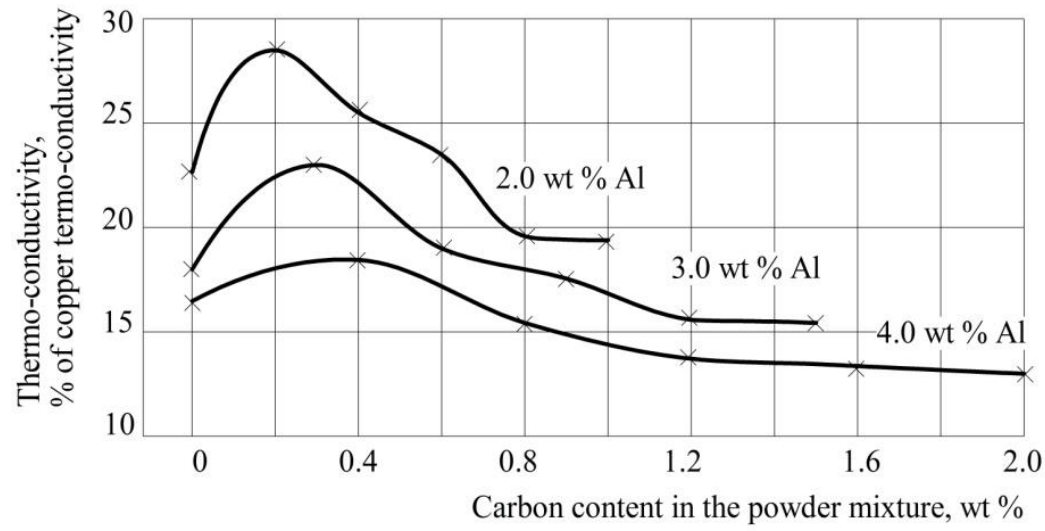

Fig. 3. Diagrams of dependency of relative thermo-conductivity of materials under analysis on their aluminum and carbon content.

Fig. 2 and Fig.3 show that for every certain aluminum content there is an optimal carbon quantity with which the material has the highest hardness or thermo-conductivity. In particular, the maximum hardness value is reached at about $0.4 \mathrm{wt}$ carbon per $1 \mathrm{wt}$ aluminum, while the maximum thermal conductivity value is at $0.1 \mathrm{wt}$ carbon per $1 \mathrm{wt}$ aluminum.

Analysis of the diagrams in Fig. 2 and Fig.3 as well as the tensile strength and elongation values showed that the materials given in Table 2 have the best combination of such parameters as hardness, elongation (characterizes process properties of the material its ductility) and thermo-conductivity. 
Table 2. Properties of materials under analysis with the most optimal chemical composition

\begin{tabular}{|c|c|c|c|c|}
\hline \multicolumn{2}{|l|}{ Conventional designation of material } & $\mathrm{Cu}-2 \mathrm{Al}-0,8 \mathrm{C}$ & $\mathrm{Cu}-3 \mathrm{Al}-0,9 \mathrm{C}$ & $\mathrm{Cu}-4 \mathrm{Al}-$ \\
\hline \multirow[t]{2}{*}{ Initial content of elements, wt $\%$} & $\mathrm{Al}$ & 2.0 & 3.0 & 4.0 \\
\hline & $\mathrm{C}$ & 0.8 & 0.9 & 0.8 \\
\hline \multicolumn{2}{|l|}{ Ultimate tensile strength, $\mathrm{MPa}$} & 838 & 836 & 850 \\
\hline \multicolumn{2}{|l|}{ Elongation, \% } & 1.7 & 2.5 & 2,0 \\
\hline \multicolumn{2}{|l|}{ HV hardness, MPa } & 2380 & 2330 & 2540 \\
\hline \multicolumn{2}{|l|}{$\begin{array}{l}\text { Thermo-conductivity, } \% \text { of thermo- } \\
\text { conductivity of copper }\end{array}$} & 19.6 & 17.4 & 15.2 \\
\hline
\end{tabular}

The results of the tests of pads made of these materials in coupling with a chromiumplated steel roller on the friction machine using the above described methods are given in Table 3.

Table 3. Comparative measures of wear and score resistance of materials under analysis and «padroller» friction coupling.

\begin{tabular}{|l|c|c|c|c|}
\hline \multirow{2}{*}{ Pad material } & \multicolumn{3}{|c|}{ Materials under analysis } & $\begin{array}{c}\text { Reference } \\
\text { material }\end{array}$ \\
\cline { 2 - 5 } & Cu-2Al-0,8C & Cu-3Al-0,9C & Cu-4Al-0,8C & $\begin{array}{c}\text { Bronze F65 } \\
\text { DIN 17666 }\end{array}$ \\
\hline Vickers hardness, MPa & 2380 & 2330 & 2540 & 2250 \\
\hline Specific wear of pad, mm/km & 0.020 & 0.024 & 0.017 & 0.403 \\
\hline Specific wear of roller, mg/km & 0.039 & 0.028 & 0.044 & 0.036 \\
\hline $\begin{array}{l}\text { Wear resistance coefficient of tested } \\
\text { material in relation to bronze F65 }\end{array}$ & 20.2 & 16.8 & 23.7 & 1 \\
\hline $\begin{array}{l}\text { Wear resistance coefficient of the } \\
\text { friction coupling with the pad made } \\
\text { of the tested material in relation to } \\
\text { friction coupling with the pad made } \\
\text { of bronze F65 }\end{array}$ & 18.7 & 21.6 & 19.4 & 1 \\
\hline Specific seizure load, MPa & 62.8 & 66.3 & 45.8 & 16.9 \\
\hline $\begin{array}{l}\text { Score resistance coefficient of tested } \\
\text { material in relation to bronze F65 }\end{array}$ & 3.7 & 3.9 & 2.7 & 1.00 \\
\hline
\end{tabular}

It follows from Table 3 that the best tribotechnical properties are exhibited by the copper material with $\mathrm{Cu}-3 \mathrm{Al}-0,9 \mathrm{C}$ conventional designation, which contains $0.9 \mathrm{wt} \%$ aluminum, $0.3 \mathrm{wt} \%$ carbon, 0.4 wt $\%$ iron and 0.017 wt $\%$ oxygen. It surpasses CuNi2Si (F65 DIN 17666) bronze widely used by many leading engine-making companies for manufacturing of valve guides by the wear resistance coefficient almost 17 times and by the score resistance coefficient almost 4 times.

We should also note that the other two materials also greatly surpass F65 bronze by the given parameters, however they are inferior to $\mathrm{Cu}-3 \mathrm{Al}-0,9 \mathrm{C}$ material. Therefore, all further research was conducted for this very material.

The mechanical tests of the given material showed that it has an extremely high recrystallization temperature equal to $1000^{\circ} \mathrm{C}$, which is higher than the heating temperature of valve guides, and its «hot» hardness at equal temperatures is above the same characteristic of heat-resistance bronzes. This makes it possible to classify this material as a heat-resistance material. At that, the material has a high thermo-conductivity $(65.0$ $\mathrm{W} / \mathrm{m} \cdot{ }^{\circ} \mathrm{C}$ at $25^{\circ} \mathrm{C}$ and $56.4 \mathrm{~W} / \mathrm{m}^{\circ}{ }^{\circ} \mathrm{C}$ at $400^{\circ} \mathrm{C}$ ) and a low linear thermal expansion coefficient $\left(17.4 \cdot 10^{-6} 1 /{ }^{\circ} \mathrm{C}\right.$ at $20 \ldots 100^{\circ} \mathrm{C}$ and $22.9 \cdot 10^{-6} 1 /{ }^{\circ} \mathrm{C}$ at $\left.800 \ldots 900^{\circ} \mathrm{C}\right)$.

Analysis of the obtained properties let us conclude that the developed materials and, first of all, $\mathrm{Cu}-3 \mathrm{Al}-0,9 \mathrm{C}$, by their properties meet the above given requirements that have to 
be imposed on modern and promising materials for valve guides of powerful internal combustion engines. This became possible due to not only a suitable chemical composition but peculiarities of the structure of developed materials, too.

In particular, the heat resistance and high wear resistance of developed materials are explained by their fine structure (Fig.4), consisting, according to corresponding research, of copper, $\alpha-\mathrm{Cu}(\mathrm{Al})$, dynamically heat-stable particles $\gamma-\mathrm{Al}_{2} \mathrm{O}_{3}$ and residual carbon $(0.70 \ldots 0.73$ wt \%).

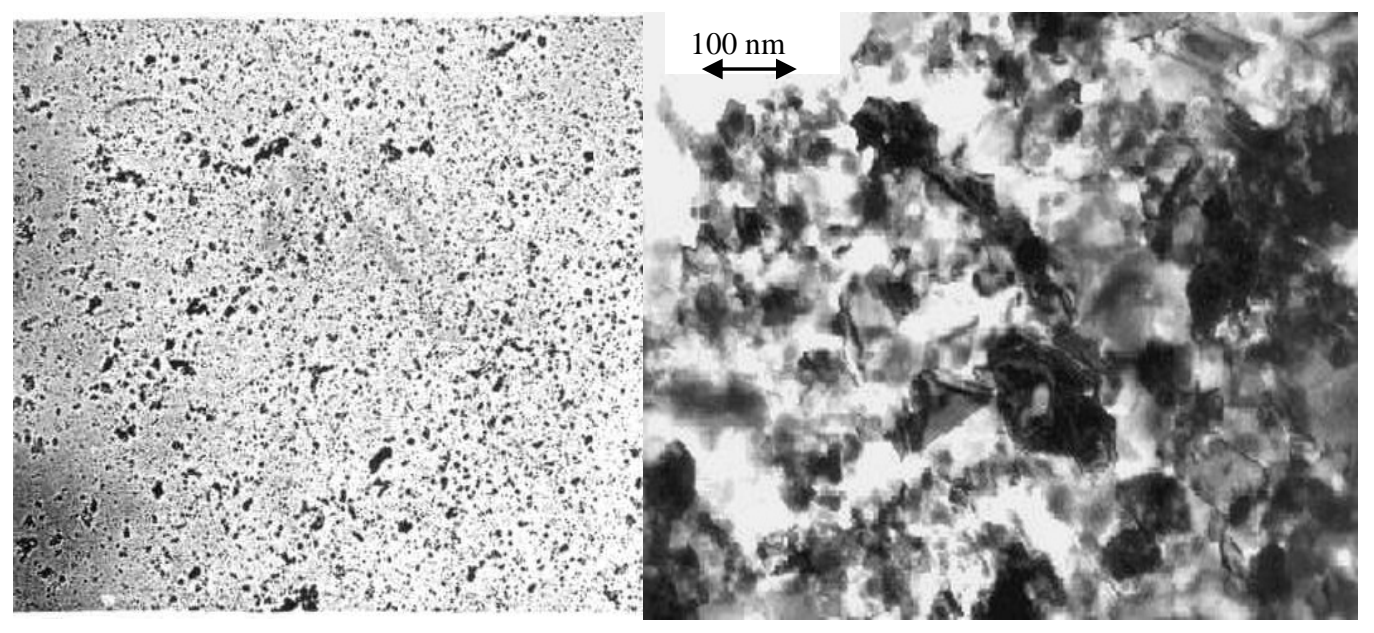

a)

b)

Fig. 4. Fine structure of $\mathrm{Cu}-3 \mathrm{Al}-0,9 \mathrm{C}$ nanocomposite material: a) x 20000 (TEM, carbon replica); b) $\mathrm{x} 57000$ (TEM, foil).

Stereological analysis of extraction carbon replicas (Fig.4,a) showed that the average size of strengthening phase particles $\left(\gamma-\mathrm{Al}_{2} \mathrm{O}_{3}\right)$ is about $36 \mathrm{~nm}$, their volume fraction in the material is $14.8 \%$, and the average distance between centers of particles is $530 \mathrm{~nm}$. The foil photo (Fig.4,b) shows that the material has a well-developed subgrain structure of the nano-disperse range, which is a sign of no recrystallization of alloyed copper during hot $\left(850^{\circ} \mathrm{C}\right)$ extrusion of its granules in a bar. The electron diffraction pattern for this foil shows that the subgrain structure of the material has a high degree of polycrystallinity (presence of corresponding rings on the electron diffraction pattern).

Thanks to the above-mentioned peculiarities of the fine structure of developed materials they can be classified as nanocomposite materials.

\section{Conclusions}

Due to their physical and mechanical properties the developed copper nanocomposite powder materials containing aluminum, carbon, iron and oxygen additives and having a dispersion-strengthened structure can be recommended as an alternative to modern copper alloys used in valve guides of powerful internal combustion engines.

\section{References}

1. B. Stojanovic, J. Glisovic, Automotive engine materials, Reference Module in Materials Science and Materials Engineering, ed. S. Hashmi, pp. 1-9 (Elsevier, Oxford, 2016) 
2. L.I. Myagkov, K. Mahkamov, N.D. Chainov, I. Makhkamova, Advanced and conventional internal combustion engine materials, Fuels and Advanced Vehicle Technologies for Improved Environmental Performance: Towards Zero Carbon Transportation, ed. R. Folkson, pp. 370-392 (Woodhead Publishing, Oxford, 2014)

3. J.S. Sidhu, G.S. Lathkar, S.B. Sharma, Design of epoxy based resin composites for automotive applications: a case study on ic engine valve guide, Journal of the Institution of Engineers (India): Series C, v. 100, 2, pp. 283-288 (2019)

4. N. Hort, K.U. Kainer, Powder metallurgically manufactured metal matrix composites, Metal matrix composites: custom-made materials for automotive and aerospace engineering, ed. K.U. Kainer, pp.243-274 (Wiley-VCH Verlag, Weinheim, 2006)

5. R. Van Basshuysen, F. Schäfer, Handbuch Verbrennungsmotor: Grundlagen, Komponenten, Systeme, Perspektiven, 8. überarbeitete Auflage (Springer Vieweg, Wiesbaden 2017)

6. E.P. Shalunov, S.A. Orlov, V.S. Slavoljubov, Proc. Int. Conf. on Science for Materials in the Frontier of Centuries: Advantages and Challenges (Kyiv, Ukraine), v. 2, pp. 599600 (Frantsevich IPMS, Kyiv, 2002)

7. H. Kawata, K. Maki, Hitachi Powdered Metals Technical Report, v. 6, pp.1-11 (2007)

8. B. Venkatesh, B. Harish, International Journal of Engineering Research and General Science, v. 3, 1, pp.1277-1284 (2015)

9. K. Siczek, Researces on friction force between valve made of TiAl and its guide made of phosphorous bronze,Journal of KONES Powertrain and Transport,v.20,1,pp.295301(2013)

10. M. Slesar, G. Jangg, M. Besterci, Festigkeit und Bruch dispersionsgehärteter $\mathrm{Cu}-\mathrm{Al}_{2} \mathrm{O}_{3}$ Werkstoffe, Z. für Metallkunde, v. 72, 6, S.423-427 (1981)

11. C. Suryanarayana, Mechanical alloying and milling,Progress in Materials Science,46,pp.1-18 (2001)

12. V. Dovydenkov, E. Shalunov, Proc.of Powder Metallurgy - 1998 World Congress, v.l,pp.372-376 (EPMA, Granada, 1998)

13. E. Shalunov, A. Matrosov, L. Chen, Proc. of Int. Congress \& Exhibition on Powder Metallurgy (Euro PM - 2008), v.1, pp.113-119 (EPMA, Mannheim, 2008)

14. Y. O. Vladimirova, E. P. Shalunov, Nanocomposite copper powder based material and technique of its obtaining used for plungers of die-casting machines, IOP Conf. Series: Materials Science and Engineering, v. 525, 1 (2019)

15. S.A. Saltykov, Stereometric metallography (Metallurgia, Moscow, 1970) (in Russian) 